\title{
The Secretion of $N$-Acetylglucosaminidase during Germ-tube Formation in Candida albicans
}

\author{
By PATRICK. A. SULLIVAN, ${ }^{1 *}$ NICOLA J. MCHUGH, \\ LAJWANT K. ROMANA ${ }^{1}$ AND MAXWELL G. SHEPHERD ${ }^{2}$ \\ Department of Biochemistry ${ }^{1}$ and Experimental Oral Biology Unit ${ }^{2}$, University of Otago,
}

PO Box 56, Dunedin, New Zealand

(Received 20 December 1983; revised 21 March 1984)

\begin{abstract}
$\mathrm{N}$-Acetylglucosaminidase was induced by either $N$-acetylglucosamine or $N$-acetylmannosamine in several strains of Candida albicans. Enzyme activity was not induced in a $N$-acetylglucosamine non-utilizing mutant which is unable to express the first three steps in the $\mathrm{N}$-acetylglucosamine catabolic pathway. The enzyme, purified 500 -fold, had a specific activity of 36.8 units (mg protein $)^{-1}$ and catalysed the hydrolysis of $p$-nitrophenyl- $\beta$ - $n$-acetylglucosamine, $N, N^{\prime}$ diacetylchitobiose and $N, N^{\prime}, N^{\prime \prime}$-triacetylchitotriose. No activity was observed toward colloidal chitin, hyaluronic acid or mucin. The cellular distribution of $N$-acetylglucosaminidase was determined by measuring in situ enzyme activity before and after acid treatment of intact cells. $\mathrm{N}$-Acetylglucosaminidase ( $80-88 \%$ of the total cellular activity) was rapidly secreted to the periplasm when the enzyme was induced either during yeast growth at $28{ }^{\circ} \mathrm{C}$ or germ-tube formation at $37^{\circ} \mathrm{C}$. Export of the enzyme from the periplasm into the medium was fourfold greater during germ-tube formation, and after $6 \mathrm{~h}$ incubation the amount of enzyme released into the medium represented $70 \%$ of cell-associated enzyme activity.
\end{abstract}

\section{INTRODUCTION}

$\mathrm{N}$-Acetylglucosamine (GlcNAc) (Simonetti et al., 1974) and some related $\mathrm{N}$-acetylhexosamine derivatives (Sullivan \& Shepherd, 1982; Shepherd \& Sullivan, 1983) induce germ-tube formation when yeast cells of $C$. albicans are incubated at $37^{\circ} \mathrm{C}$. Further, the enzymes of the GlcNAc pathway are induced at both $28^{\circ} \mathrm{C}$, without the dimorphic transition, and at $37^{\circ} \mathrm{C}$ (Shepherd et al., 1980 b; Gopal et al., 1982). In this paper we describe the properties of a secreted $N$-acetyl- $\beta$-glucosaminidase which is induced in $C$. albicans by GlcNAc. This enzyme is exported into the medium during germ-tube formation.

\section{METHODS}

Organisms. The following strains of Candida albicans were used in this work: ATCC 10261; CA2 and A72, kindly provided by Dr A. Cassone, Istituto Superiore di Sanita, Rome; hOG301, a mycelial mutant, and hOG298, an adenine-requiring GIcNAc non-utilizing mutant. The hOG strains were isolated from strain ATCC 10261 and kindly provided by Dr R. T. M. Poulter, Biochemistry Department, University of Otago.

Growth, germ-lube formation and enzyme induction. The maintenance of yeast cultures, growth of yeast batchcultures (Shepherd \& Sullivan, 1976), preparation of starved yeast cells, conditions for germ-tube formation (Shepherd et al., 1980a) and enzyme induction (Gopal et al., 1982) have been described previously. Adenine $(3.0 \mathrm{mM})$ was included in the media used for strain hOG298. Unless otherwise stated inducers were added to the medium at a final concentration of $2.5 \mathrm{~mm}$. For germ-tube formation starved cells $\left(4 \times 10^{7} \mathrm{cells}^{-1}\right)$ and inducer were incubated at $37^{\circ} \mathrm{C}$ in $10 \mathrm{~mm}$-imidazole $/ \mathrm{HCl}$ buffer, $\mathrm{pH} 6.6$ containing $0.1 \mathrm{~mm}-\mathrm{MnCl}_{2}$. In one experiment (illustrated in Fig. 1) starved yeast cells were incubated in salts/biotin medium minus the glucose and $\left(\mathrm{NH}_{4}\right)_{2} \mathrm{SO}_{4}$

Abbreviations: GlcNAc, $N$-acetylglucosamine; pNP-GlcNAc, $p$-nitrophenyl- $\beta$ - $N$-acetylglucosamine. 
(Shepherd et al., 1980a) but containing $10 \mathrm{~mm}$-GlcNAc at $28^{\circ} \mathrm{C}$ for yeast growth and $37^{\circ} \mathrm{C}$ for germ-tube formation. Yeast-budding and germ-tube formation were assessed by phase-contrast microscopy (Shepherd et al., 1980 a). Yeast-phase growth was determined from the $\mathrm{OD}_{540}$ (Sullivan \& Shepherd, 1982).

Enzyme preparations. Cell-free extracts were prepared in either $0.01 \mathrm{M}$ - or $0.1 \mathrm{M}$-potassium phosphate buffer, pH 6.95, as indicated, with a Braun homogenizer (B. Braun, Melsungen, FRG) (Gopal et al., 1982). Permeabilized cells were prepared for in situ assays essentially as described by Ram et al. (1983); cell suspensions (1.2-1.6 $\times 10^{9}$ cells $\mathrm{ml}^{-1}$ in $0.1 \mathrm{M}$-potassium phosphate buffer, containing $\left.0.01 \mathrm{M}-\mathrm{MgCl}_{2}\right)$ were shaken with $10 \%(\mathrm{v} / \mathrm{v})$ toluene/ethanol/Triton X-100 (1:4:0.2, by vol.) for $5 \mathrm{~min}$ at $4{ }^{\circ} \mathrm{C}$ and washed twice with $0 \cdot 1 \mathrm{M}$-potassium phosphate buffer, pH 6.95.

The cellular distribution of $\mathrm{N}$-acetylglucosaminidase was determined by measuring in situ enzyme activity before and after treatment of intact cells with $0.1 \mathrm{M}-\mathrm{HCl}$ (Ram et al., 1984). Washed cells were resuspended in $0.1 \mathrm{M}-\mathrm{HCl}$ at $4{ }^{\circ} \mathrm{C}$, incubated for $15 \mathrm{~min}$, neutralized with $\mathrm{NaOH}$ and washed three times with the potassium phosphate buffer. Exported $\mathrm{N}$-acetylglucosaminidase was measured in concentrated culture supernatants. Each culture sample was centrifuged $(3000 \mathrm{~g}, 10 \mathrm{~min})$, the supernatant was concentrated 50 -fold by dialysis against polyethylene glycol (20000) and finally dialysed against distilled water.

Enzyme assay. The assay system for $\beta$ - $N$-acetyl-D-glucosaminidase (EC 3.2.1.30) contained in $0.5 \mathrm{ml}: 30 \mu \mathrm{mol}$ potassium phosphate buffer, $\mathrm{pH} 6.95,3 \mu \mathrm{mol} p$-nitrophenyl- $\beta$ - $N$-acetylglucosamine (pNP-GlcNAc) and 0.02 $0.2 \mathrm{ml}$ enzyme solution or permeabilized cells suspension. The assays were incubated for a fixed time (up to $30 \mathrm{~min}$ ) at $37^{\circ} \mathrm{C}, 2 \mathrm{ml} 4 \% \mathrm{Na}_{2} \mathrm{CO}_{3}$ was added, the tubes were centrifuged and the $A_{420}$ was read against a blank which contained buffer and pNP-GIcNAc. A unit of enzyme activity catalyses the formation of $1 \mu$ mol $p$ nitrophenol per $\min \left(\varepsilon 16.0 \times 10^{3} 1 \mathrm{~mol}^{-1} \mathrm{~cm}^{-1}\right)$. Protein was estimated by the modified Lowry method (Eggstein \& Kreutz, 1967) with crystalline bovine serum albumin as a standard. Enzyme activity is expressed either as units (mg protein $)^{-1}$ or units $\left(10^{10} \text { cells }\right)^{-1}$.

Estimation of GlcNAc. This was done by the method of Reissig et al. (1955).

HPLC gel permeation chromatography. The HPLC gel permeation chromatography columns used in the enzyme purification were a GSWP pre-column $(7.5 \times 75 \mathrm{~mm})$ and a G3000 SW fractionation column $(7.5 \times 1200 \mathrm{~mm})$ obtained from the Toya Soda Manufacturing Co., Nan-Yo, Yamaguichi, Japan.

Purification of the enzyme. Strain CA2 was grown for $16 \mathrm{~h}$ at $28^{\circ} \mathrm{C}$, harvested and incubated with GlcNAc for 2 h to induce $N$-acetylglucosaminidase. These cells $(11 \mathrm{~g}$, wet wt) were disrupted in $0.01 \mathrm{M}$-potassium phosphate buffer, pH 6.95, and the enzyme was adsorbed batchwise onto $120 \mathrm{ml}$ bed volume of DEAE-Sephacel equilibrated with $10 \mathrm{~mm}$-potassium phosphate, pH 6.95. The DEAE-Sephacel was washed three times with $80 \mathrm{ml}$ buffer and the enzyme was eluted with five washes of buffer containing $100 \mathrm{mM}-\mathrm{NaCl}$. The combined eluate $(200 \mathrm{ml})$ was dialysed overnight against $1 \mathrm{~mm}$-potassium phosphate buffer, pH $6.95(2 \times 21)$, concentrated to $10 \mathrm{ml}$ with a Millipore Pellicon membrane (exclusion limit $10000 \mathrm{Dal}$ ) and lyophilized. The freeze-dried preparation was dissolved in distilled water $(3 \mathrm{ml})$ and two $1.3 \mathrm{ml}$ samples were fractionated on a TSK GSW3000 HPLC gel permeation column $(0.7 \mathrm{~cm} \times 1.2 \mathrm{~m})$ equilibrated with $10 \mathrm{~mm}$-potassium phosphate buffer, $\mathrm{pH} 6.95$. The flow rate was $0.6 \mathrm{ml} \mathrm{min}^{-1}$. Fractions $(0.6 \mathrm{ml})$ containing enzyme activity were pooled, dialysed against distilled water, lyophilized and rerun through the column. The final preparation contained insufficient protein for a Lowry estimation but the protein content determined by the dye-binding method (Bradford, 1976) indicated that the specific activity was 36.8 units (mg protein) ${ }^{-1}$. This represented a 500 -fold purification with a $12 \%$ recovery. $\mathrm{N}$-Acetylglucosaminidase partially purified by the same procedure from strain ATCC 10261 had a specific activity of 2 units (mg protein) $)^{-1}$.

Materials. $p$-Nitrophenyl derivatives, $N$-acetylamino sugars, hyaluronic acid and naphthol AS-LC $N$-acetyl- $\beta$ glucosamine were obtained from Sigma. Colloidal chitin was prepared by the method of Jeuniaux (1966) from crab shells. Mucin, purified from pig intestine, was kindly provided by $\operatorname{Dr}$ A. M. Roberton, Biochemistry Department, University of Auckland, New Zealand. Naphthyl- $\beta$ - $N$-acetylglucosamine was obtained from Serva, Heidelberg, FRG.

\section{RESULTS}

\section{Induction of $\mathrm{N}$-acetylglucosaminidase}

During studies on GlcNAc-induced germ-tube formation in $C$. albicans it was noted that permeabilized cells contained $N$-acetylglucosaminidase activity. The enzyme was induced by either GlcNAc or $N$-acetylmannosamine and at $28^{\circ} \mathrm{C}$ (yeast growth) or $37^{\circ} \mathrm{C}$ (germ-tube formation). After $3 \mathrm{~h}$ incubation at $28^{\circ} \mathrm{C}$ the specific activity in ATCC 10261 was 0.6 units $\left(10^{10}\right.$ cells $)^{-1}$ with GIcNAc and $0 \cdot 5$ units $\left(10^{10} \text { cells }\right)^{-1}$ with $N$-acetylmannosamine. The enzyme was not induced by glucose, hyaluronic acid $\left(0.2 \mathrm{mg} \mathrm{ml}^{-1}\right)$, chitin $\left(0.2 \mathrm{mg} \mathrm{ml}^{-1}\right)$, chitin plus glucose, glucose plus glutamine, mucin $\left(1 \mathrm{mg} \mathrm{ml}^{-1}\right)$, peptone $(0.2 \%, \mathrm{w} / \mathrm{v})$ or serum $(1 \%, \mathrm{v} / \mathrm{v})$. All the 
Table 1. $N$-Acetylglucosaminidase activity in strains of $C$. albicans

Enzyme activity was induced with GlcNAc and measured in the in situ assay system. The values in parentheses were obtained with cells incubated in buffer without GlcNAc. The values shown are the means of duplicate determinations.

\begin{tabular}{lc}
\multicolumn{1}{c}{ Strain } & \multicolumn{1}{c}{$\begin{array}{c}\text { Activity } \\
\text { [units }\left(10^{10} \text { cells }\right)^{-1} \text { ] }\end{array}$} \\
ATCC 10261 & $0 \cdot 85(0.05)$ \\
A72 & $2 \cdot 5(0.03)$ \\
CA2 & $5 \cdot 5(0.05)$ \\
hOG298 & $0(\mathrm{NT})$ \\
hOG301 & $0.65(0.03)$
\end{tabular}

NT, Not tested.

Table 2. Purification of $N$-acetylglucosaminidase

$\mathrm{N}$-Acetylglucosaminidase was purified from strain CA2 yeast cells as described in the text.

$\begin{array}{lcccc} & \begin{array}{c}\text { Total } \\ \text { Vol. } \\ \text { Fraction }\end{array} & \begin{array}{c}\text { Total } \\ \text { (units) }\end{array} & \begin{array}{c}\text { protein } \\ (\mathrm{mg})\end{array} & \begin{array}{c}\text { Specific activity } \\ \text { [units (mg protein) }\end{array} \\ & 20 & 12 \cdot 1 & 168 & 0.072 \\ \text { ract } & 200 & 5 \cdot 2 & 20 & 0.26 \\ \text { A-Sephacel step } & 3 & 3.3 & 6 & 0.55 \\ \text { lization } & 2 & 1.8 & 0.4 & 4.5 \\ \text { from gel permeation } & 2.8 & 1.40 & 0.038 & 36.8\end{array}$

\section{Cell-free extract}

After DEAE-Sephacel step

After lyophilization

Concentrate from gel permeation chromatography

After the second gel permeation step

components listed except glucose and peptone induced germ-tube formation at $37^{\circ} \mathrm{C}$; hyaluronic acid, chitin and mucin did not support growth. $\mathrm{N}$-Acetylglucosaminidase was induced by GlcNAc in all strains tested except hOG298, the GlcNAc non-utilizing mutant (Table 1). The data given represent typical examples of experiments which were repeated with duplicate assays (SE $<10 \%$ ). The variability between experiments was less than $20 \%$.

\section{Purification and properties}

A rapid and effective purification of $N$-acetylglucosaminidase was achieved with ionexchange chromatography and gel permeation HPLC (Table 2). After the second passage through the HPLC column a single symmetrical peak wasobtained. $N$-Acetylglucosaminidase was stable for several weeks at $4{ }^{\circ} \mathrm{C}$ and indefinitely at $-20^{\circ} \mathrm{C}$. In potassium phosphate buffers the enzyme exhibited a broad $\mathrm{pH}$-activity curve with a maximum at $\mathrm{pH} 6.5$. The $K_{\mathrm{m}}$ for $\mathrm{pNP}$ GlcNAc under standard assay conditions was $0.45 \mathrm{mM}$. No activity was observed with the following compounds each at $5 \mathrm{~mm}$ : $p$-nitrophenyl- $\alpha$ - or $-\beta$-glucoside, $p$-nitrophenyl- $\alpha$ - or $-\beta$ mannoside and $p$-nitrophenyl- $\beta$-diacetylchitobiose. The enzyme did not produce GlcNAc from chitin $(0.04 \mathrm{mg})$, hyaluronic acid $(0.05 \mathrm{mg})$ or mucin $(0.4 \mathrm{mg})$ when these compounds were added to the standard system. However, as shown in Table 3, the enzyme hydrolysed diacetylchitobiose and triacetylchitotriose. The elution volume for $\mathrm{N}$-acetylglucosaminidase from the gel permeation column was $26.4 \mathrm{ml}$, similar to that for ovalbumin $(26 \mathrm{ml})$ which has a molecular weight of 44000 . In SDS-polyacrylamide gel electrophoresis however, the purified enzyme from strain CA2 showed two overlapping bands which migrated as a protein of molecular weight 66000 .

\section{Secretion of $\mathrm{N}$-acetylglucosaminidase}

Cell viability and the capacity to form germ-tubes is unaffected when $C$. albicans cells are suspended in $0.1 \mathrm{M}-\mathrm{HCl}$ at $4{ }^{\circ} \mathrm{C}$ for $15 \mathrm{~min}$. However, enzymes associated with the cell wall and periplasmic space are inactivated by this treatment (Ram et al., 1984). A preliminary 

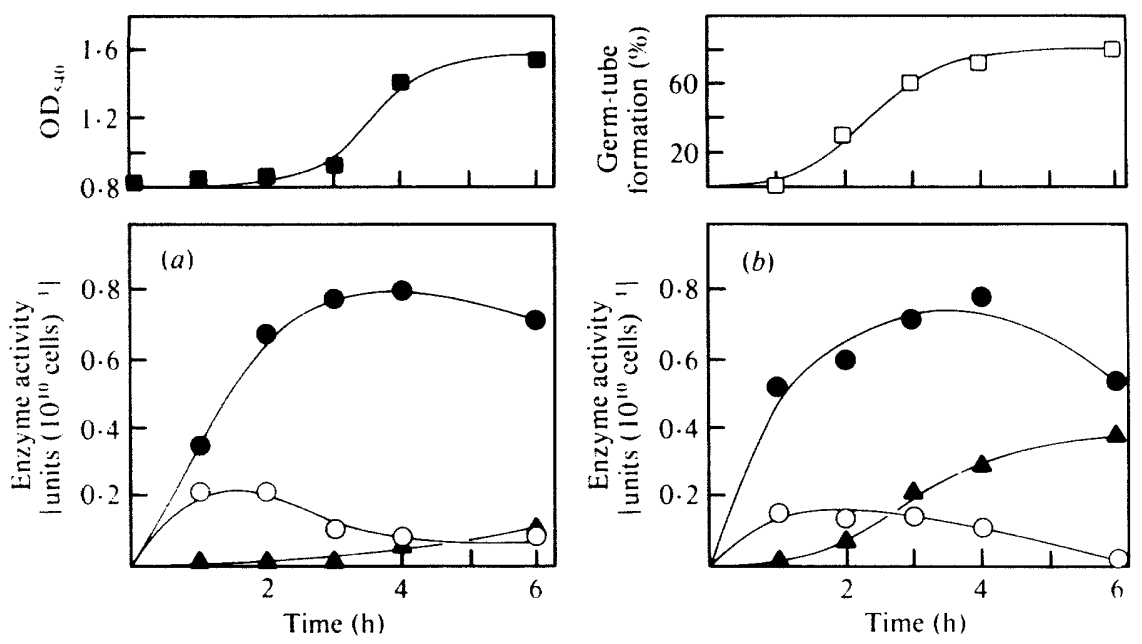

Fig. 1. Induction and secretion of $N$-acetylglucosaminidase. Starved yeast cells of strain ATCC 10261 were incubated at $8 \times 10^{7}$ cells $\mathrm{ml}^{-1}$ in salts/biotin medium containing $10 \mathrm{~mm}$-GlcNAc. Yeast growth at $28^{\circ} \mathrm{C}(\square)$ was measured at $540 \mathrm{~nm}$, and germ-tube formation $(\square)$ at $37^{\circ} \mathrm{C}$ was assessed by phasecontrast microscopy. At the times indicated total in situ activity $(\bigcirc)$, acid-resistant in situ activity $(O)$ and enzyme exported to the medium $(\boldsymbol{A})$ were measured during yeast growth $(a)$ and germ-tube formation $(b)$. The values shown are the means of at least two determinations. Experiments were reproducible with variation of $<20 \%$.

\section{Table 3. Substrate specificity of $N$-acetylglucosaminidase}

Purified $\mathrm{N}$-acetylglucosaminidase from strain CA2 was incubated with the compounds listed (5 mM final concentration) under standard assay conditions. Activity towards each of the $p$-nitrophenyl derivatives was measured by the release of $p$-nitrophenol. Activity towards the other substrates was determined by the formation of GlcNAc as summarized in Methods.

\section{Substrate}

$p$-Nitrophenyl- $\beta$ - $N$-acetylglucosamine

$p$-Nitrophenyl- $\beta$ - $N$-diacetylchitobiose

Diacetylchitobiose

Triacetylchitotriose

Naphthyl- $\beta$ - $N$-acetylglucosamine

Naphthol AS-LC $N$-acetyl- $\beta$-D-glucosamine

$$
\begin{gathered}
\text { Activity } \\
\left(\mu \mathrm{mol} \mathrm{min}^{-1} \mathrm{mg}^{-1}\right)
\end{gathered}
$$

17
0
$11 \cdot 5$
$3 \cdot 3$
0
0

experiment showed that more than $80 \%$ of the in situ $\mathrm{N}$-acetylglucosaminidase was inactivated by acid treatment. Therefore the rates of induction, secretion and the release of the enzyme into the medium were measured during yeast growth at $28^{\circ} \mathrm{C}$ and germ-tube formation at $37^{\circ} \mathrm{C}$. In the GlcNAc/salts/biotin medium at $28{ }^{\circ} \mathrm{C}$ more than $80 \%$ of the cells formed buds and daughter cells. After $6 \mathrm{~h}$ incubation the cell density had doubled. At $37{ }^{\circ} \mathrm{C}$ more than $80 \%$ of the cells formed germ-tubes and after $6 \mathrm{~h}$ hyphae were four to five times the mother cell diameter in length (Fig. 1). The apparent rate of enzyme synthesis (total in situ activity) was faster at $37^{\circ} \mathrm{C}$ during the first hour but beyond $2 \mathrm{~h}$ the total in situ activity in the yeast cells $\left(28^{\circ} \mathrm{C}\right)$ was greater. $\mathrm{N}$-Acetylglucosaminidase was secreted to the periplasmic space during yeast growth and germtube formation as judged by the effect of acid treatment prior to an in situ assay; after $3 \mathrm{~h}$ incubation $88^{\circ}$ and $80 \%$, respectively, of the total in situ activity was acid-labile (i.e. associated with the wall and periplasmic space). The enzyme was released into the medium at a much higher rate during germ-tube formation. After $3 \mathrm{~h}$ incubation no enzyme was detected in the yeast growth medium but the enzyme exported by the germ-tube forming cells represented $29 \%$ 
of the total in situ activity. At $6 \mathrm{~h}$ the exported enzyme was $14 \%$ and $70 \%$ of the total cellular enzyme for the yeast and hyphal cultures, respectively.

\section{DISCUSSION}

$N$-Acetylglucosaminidase was induced gratuitously by either GlcNAc or $N$-acetylmannosamine. Since the enzyme hydrolysed diacetylchitobiose and to a lesser extent triacetylchitotriose it could participate in the degradation of small oligomers arising from chitin. Further, it is possible that the enzyme can remove terminal GlcNAc residues from glycopeptides and glycans although it exhibited no activity towards chitin, mucin or hyaluronic acid. The SDS-PAGE and gel permeation chromatography data suggest that the native enzyme is a monomer with a molecular weight of 66000 , although it has been found that a number of proteins of known molecular weights do not exhibit predicted elution volumes in the HPLC gel permeation columns (P. A. Sullivan, unpublished results).

All the strains of $C$. albicans tested except hOG298 possessed the inducible $N$-acetylglucosaminidase. The mutant hOG298 is unable to induce the GlcNAc uptake system, GlcNAc-kinase and GlcNAc-6-phosphate deacetylase (B. E. Corner, R. T. M. Poulter, M. G. Shepherd \& P. A. Sullivan, unpublished results). The present results suggest that induction of $\mathrm{N}$-acetylglucosaminidase may be co-ordinated with induction of the permease and catabolic enzymes. Consistent with this suggestion, it was previously found that $N$-acetylmannosamine is not taken up by $C$. albicans but that it is a gratuitous inducer for the permease and the catabolic enzymes (Sullivan \& Shepherd, 1982).

Pugh \& Cawson (1977) reported a cytochemical detection of $N$-acetylglucosaminidase in $C$. albicans. The enzyme was reported to be secreted around the entire yeast cell, associated with intracellular vesicles and was secreted by germ-tube forming cells. In the present study more than $80 \%$ of the enzyme was secreted as judged by the acid lability in intact cells. It was not, however, tightly associated with the cell wall since all $(>95 \%)$ of the total activity was recovered in the soluble fraction after cell disruption (data not shown). Following enzyme induction $\mathrm{N}$ acetylglucosaminidase was rapidly secreted to the periplasm of cells grown at both $28^{\circ} \mathrm{C}$ and $37^{\circ} \mathrm{C}$ but export of the enzyme to the medium was fourfold greater during hyphal formation. Recently we found that exo-( $1 \rightarrow 3)-\beta$-glucanase was secreted and exported in $C$. albicans during germ-tube formation but negligible enzyme was released into the yeast growth medium (Ram et al., 1984). It is suggested that the germ-tube wall is more porous than that of yeast cells and consequently export of enzymes is facilitated by the formation of hyphae. The secretion of hydrolases and production of hyphae have frequently been cited as determinants of virulence in C. albicans (Odds, 1979). Recently MacDonald \& Odds (1983) reported the isolation of a protease-secretion-deficient mutant of $C$. albicans which was less virulent towards mice. Although mycelium is usually encountered in infected tissue the importance of hyphae in the development of candidosis has remained controversial (Odds, 1979). The results reported in this paper suggest that hyphal formation and the export of hydrolytic enzymes should be considered as related virulence determinants since the former facilitates the latter. Finally, it should also be noted that the appearance of an electron-transparent innermost layer in the cell wall with the onset of germ-tube formation (Cassone et al., 1973) may reflect the export of cell wall-associated proteins.

This work was supported by a grant from the Medical Research Council of New Zealand. L. K. R. is the recipient of a New Zealand Universities Grants Committee Postgraduate Scholarship.

\section{REFERENCES}

BRADFORD, M. M. (1976). A rapid and sensitive method for quantitation of microgram quantities of protein utilising the principle of protein-dye binding. Analytical Biochemistry 72, 248-254.
Cassone, A., Simonetti, N. \& Strippoli, V. (1973). Ultrastructural changes in the wall during germ-tube formation from blastospores of Candida albicans. Journal of General Microbiolog. 77, 417-426. 
Eggstein, M. \& Kreutz, F. H. (1967). In Techniques in Protein Chemistry, p. 340 . Edited by J. L. Bailey. London: Elsevier

Gopal, P., Sullivan, P. A. \& Shepherd, M. G. (1982). Enzymes of $N$-acetylglucosamine metabolism during germ-tube formation in Candida albicans. Journal of General Microbiology 128, 2319-2326,

Jeuniaux, C. (1966). Chitinases. Methods in Enzymo$\log y$ 8, 644-650.

MacDonald, F. \& OdDs, F. C. (1983). Virulence for mice of a proteinase-secreting strain of Candida albicans and a proteinase-deficient mutant. Journal of General Microbiology 129, 431-438.

ODds, F. C. (1979). Candida and Candidosis, pp. 29-41. Leicester: Leicester University Press.

Pugh, D. \& Cawson, R. A. (1977). The cytochemical localization of acid hydrolases in four common fungi. Cellular and Molecular Biology 22, 125-132.

Ram, S. P., Sullivan, P. A. \& Shepherd, M. G. (1983). The in situ assay of Candida albicans enzymes during yeast growth and germ-tube formation. Journal of General Microbiology 129, 2367-2378.

Ram, S. P., Romana, L. K., Shepherd, M. G. \& Sullivan, P. A. (1984). Exo-( $1 \rightarrow 3)-\beta$-glucanase, autolysin and trehalase activities during yeast growth and germ-tube formation in Candida albicans. Journal of General Microbiology. 130, 1227-1236.

Reissig, J. L., Strominger, J. L. \& Leloir, L. F.
(1955). A modified colorimetric method for the estimation of $N$-acetylamino sugars. Journal of Biological Chemistry 217, 959--966.

Shepherd, M. G. \& Sullivan, P. A. (1976). The production and growth characteristics of yeast and mycelial forms of Candida albicans in continuous culture. Journal of General Microbiology 93, 361-370.

ShePherd, M. G. \& Sullivan, P. A. (1983). Candida albicans germ-tube formation with immobilized GIcNAc. FEMS Microbiology Letters 17, 167-170.

ShePherd, M. G., ChIEW, Y. Y., RAM, S. P. \& Sullivan, P. A. (1980a). Germ-tube induction in Candida albicans. Canadian Journal of Microbiology 26, 21-26.

Shepherd, M. G., Ghazali, H. M. \& Sullivan, P. A. (1980b). $N$-Acetyl-D-glucosamine kinase and germtube formation in Candida albicans. Experimental Mycology 4, 147-159.

Simonetti, N., Strippoli, V. \& Cassone, A. (1974). Yeast-mycelial conversion induced by $N$-acetyl-Dglucosamine in Candida albicans. Nature, London 250, 344-346.

Sullivan, P. A. \& Shepherd, M. G. (1982). Gratuitous induction by $\mathrm{N}$-acetylmannosamine of germtube formation and enzymes for $\mathrm{N}$-acetylglucosamine utilisation in Candida albicans. Journal of Bacteriology 151, 1118-1122. 